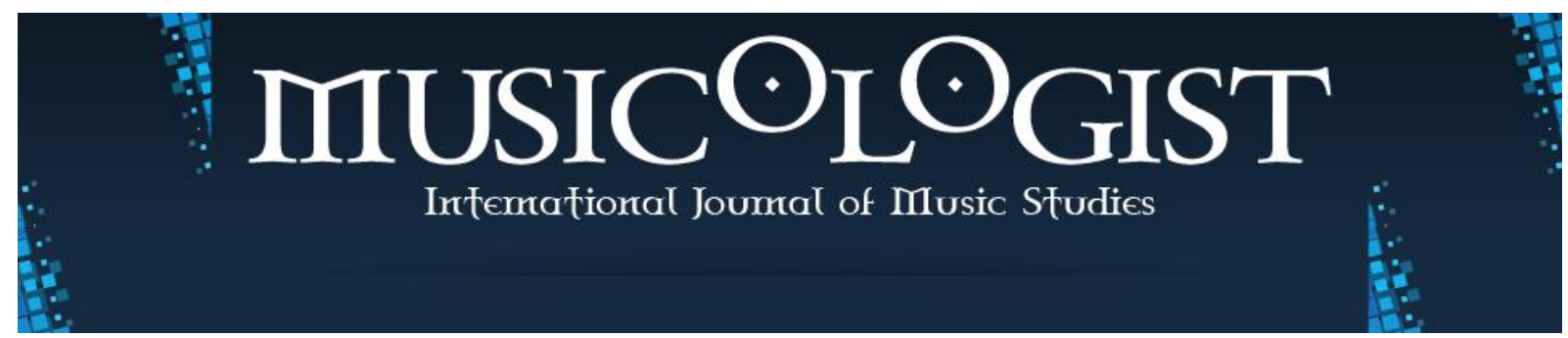

Trabzon University State Conservatory @ $2017-2020$

Volume 4 Issue 1 June 2020

Research Article Musicologist 2020. 4 (1): 34-55

DOI: $10.33906 /$ musicologist.703748

\author{
DENİZ İLBİ \\ Istanbul University (graduated), Turkey \\ denizilbi@gmail.com \\ orcid.org/0000-0002-0186-0163
}

\author{
ESRA KARAOL \\ Istanbul University, Turkey \\ esra.karaol@istanbul.edu.tr \\ orcid.org/0000-0002-9000-8430
}

\title{
Women Jazz Instrumentalists in Turkey within the Context of Gender
}

\begin{abstract}
In this work, women jazz musicians in Turkey have been examined within the gender studies context. The purpose of this research, of which its theoretical frame was formed with a socio-musicological approach, via female musicians who are active in jazz music in Turkey, is to research and form a descriptive analysis by asking questions, such as: how gender roles affect women's careers, what steps female musicians have to go through in a sector dominated by men in order to be seen and which roles are attributed to women in jazz.

Due to the fact that women jazz musicians who play instruments are a minority, the scope of the subject has been limited to 'women jazz instrumentalists in Turkey', and in-depth interviews were conducted with selected sources within this context. The boundaries of the research topic were determined by the conducted interviews, and utilizing the feminist theory, qualitative research methods were used.

With this research, an effort was made at forming a systematic reference about female jazz musicians, which was previously not found in a thorough academic research before in Turkey. The people selected for the examination of their status in the field of jazz were seen as a starting point for the research of the subject, and following the transcription of their interviews, an attempt was made to determine the causes and conclusions of gender inequalities within jazz music in Turkey. Using the implications and the results gathered during the research, there was an intention to place an emphasis on the recognition of women jazz instrumentalists beyond what's known. In conclusion, in this paper, in order to provide support to studies of musicology with a feminist approach, up to date observations were made with the examination of women jazz instrumentalists in Turkey within the gender context.
\end{abstract}

KEYWORDS
Women
Jazz
Instrument
Turkey
Gender




\section{Introduction}

This work1 constitutes a research that examines women's roles as jazz musicians in society within the gender context by using examples of women jazz musicians from Turkey.2

The observation that women jazz instrumentalists are a 'minor'ity, and fewer in numbers than males within the jazz sector in Turkey, has formed the starting point of this paper and the scope of the subject has been limited to 'women jazz instrumentalists in Turkey'. It has been determined that, although women jazz singers have largely found places for themselves on jazz stages, the ones who play instruments -and are also composers- are not as visible as singers. The purpose of this paper is to draw attention to women instrumentalists, despite their status as a minority in the jazz scene formed mostly by men, to add them to the literature and to expose the reasons as to why they are a minority and/or not as well-known.

The primary methods used in this research are the qualitative method and research techniques used in sociology, as well as musicology. The purpose of qualitative research is to understand and define the results of the research as they are, therefore, in order to understand the position of women in jazz music and the reality beyond what's known, 'in depth-interview technique' was utilized and eight women jazz musicians who had been selected as subject sources have been interviewed.

Throughout the literature search, the fact that no examples, other than Uyar's article (please refer to the bibliography), was come upon, and as research progressed, the lack of any sources in this format has supported the need for this study to be conducted. Additionally, while the above-mentioned article, written in Turkish, was focused on three women jazz pianists, within this research, the generation study exercised for the first time for Turkey's women jazz musicians indicates that the three generations (for now) of women jazz instrumentalists play instruments other than the piano, such as drums, double bass, and bass guitar, and have careers in composing, singing, band leadership and recording albums as well as their involvement in book editing and

1 This paper was produced from a master's thesis for Istanbul University Musicology Department. 2 This article, which was produced from the first author's Turkish thesis, was written in English with the intention of adding a comprehensive research about women jazz instrumentalists from Turkey to the international literature. The translation and final check was done in collaboration with native speaker Jonathan Can Uzuner Erkorkmaz. 
academic studies, such as master's/PhD theses have been brought up as up to date observations. In addition, for the first time, a space was provided for a systematic reference of the brief history of jazz music in Turkey specific to women, and the biographies of the subject sources within the master's thesis, upon which this study is based.

This paper has been created with the intent of shining a light on the identities of women jazz musicians from Turkey, who play instruments (and compose), to create a collective memory and make space for Turkish women jazz musicians in the academic record.

\section{Gender and feminist theory}

The concept of gender formed within society draws attention to the roles attributed to women and men, focuses on differences of sex built by culture. "According to Ann Oakley, who introduced the term to sociology, "Sex" refers to the biological division into male and female; "gender" to the parallel and socially unequal division into femininity and masculinity' (see Sex, Gender and Society, 1972). Gender draws attention, therefore, to the socially constructed aspects of differences between women and men." (Marshall, 1998: 250)

Feminist theory, a doctrine, which advocates for equality between genders, is a product of feminism3 that came about during the 18th century in England, and became especially prevalent from the 1970s onwards.

Feminist historians have defined three waves of feminism. With the first wave (the 19th and early 20th century) women earned their basic rights, and in time, gained admissions into the academy. Academics with the feminist approach often leaned towards the arts in the 1960s, and became interested in the discipline of musicology in the 70s.

Within the questioning of art history with the feminist approach, Linda Nochlin's article Why Have There Been No Great Women Artists?, published in 1971 plays an important part. In this work, Nochlin states that "In the former, too, 'natural' assumptions must be questioned and the mythic basis of much so-called 'fact' brought to light." (Nochlin,

\footnotetext{
3 "Histories of feminism usually assume that feminism is a western, post-Enlightenment social movement which has contributed significantly to changes both in the social situation of women and in social perceptions of women... The most usually recognized starting point of western feminism in the eighteenth century and, in particular, the publication, in 1792, of Mary Wollstonecraft's A Vindication of the Rights of Woman." (Turner, 2006: 199)
} 
2015). The feminist method used in this research too has embraced the equitable perspective and questioned the patriarchal views and traditionalist methods that leads science, just as it does every layer of society.

"Feminists ... are rewriting, redefining, and reconstructing historical and cultural thought and practice in order to repair the 'partial and sexualized character of existing theoretical knowledges.'” (Beasley, 1999: 5; as cited in Grant, 2006: 26) Specifically in this work, historical and cultural thought have been re-evaluated with a feminist perspective, while considering women's names generally being omitted from history, the literature as it was formed by the current patriarchal system, the possibility of women being left out on purpose and reparations have been attempted to the current information's gender based traits, by way of creating positive 'privilege'4/equality of opportunity to shine a light on, and to add women instrumentalists in Turkey to the literature.

The new musicology's work area has expanded with interdisciplinary research, such as feminist musicology with the cultural and historical context of music. Feminist musicology covers research that promotes musical works of neglected women and critical works on scientifically masculinized music. This work too, by focusing on determining whether it's possible for women jazz musicians whose recognition is debatable to play their instruments and compose regardless of their genders or not, adds to “'herstory' (a suggested play on words for 'history', 'history of women', an alternative to male history)" (Özkişi, 2009: 63) which itself is at the focus of feminist musicology studies.

"Is the construction of the category of women as a coherent and stable subject an unwitting regulation and reification of gender relations?" (Butler, 1990: 5) asks philosopher Judith Butler. As such, separating women based on their gender is perhaps another form of discrimination. However, as it stands, in order to provide equality between genders, descriptions such as 'woman instrumentalist', 'woman musician', 'woman composer' are used specifically to emphasize centuries of inequality/discrimination. Just as male musicians are not addressed as 'male musicians', there shouldn't be a need to address women as 'female musicians', however, to draw 
attention to the issue until women and men are socio-economically and culturally equal and women get the recognition they deserve, the 'women' prefix is going to have to be used. Only by truly gaining gender equality can the quoted terms fulfill their duty. However, until an environment free of genders is reached, in order to quickly close and equalize the gap in the historical memory, there is still need for research that shines a light on gender equality, and this article has been formed with the intent of providing aid to gender studies within the field of music.

\section{A brief history of women in jazz}

While the when and the how of the birth of jazz is a topic for debate, the common consensus among many sources is that by the end of the 1800s, slaves brought over from the continent of Africa to America, combined the rhythm and melodies unique to their culture with American music in New Orleans, where slave ships usually docked. "The art world owes jazz to the slave trade that begun during the end of the 16 th century and ended in 1865." (Mimaroğlu, 2016: 33) The social conditions that came about due to the slave trade created an effect on the Black population and has reflected on the way they express themselves and has led to the birth of jazz music.

Although the birth of jazz, which came to be as a sort of cry of racial injustice of the Black people can be interpreted as a cry of freedom, the common knowledge is that it took a longer time for Black women to take the stage as opposed to men. Jazz, in its inception was formed on the basis of discrimination and inequality as the Black people's music, so it would've only been appropriate to its roots and ideology had it empathized with and created a field of equality for women, who were living within a frame of discrimination and inequality. The fact that 200 years have passed since the birth of jazz, and women musicians are still a minority when compared to men on the jazz stage is ironic when considering the history and ideology of jazz music.

Although making significant contributions to jazz music, women jazz musicians have not received the attention they deserved, and it has been quite difficult for women to find a place in jazz playing instruments. During the first stages of jazz, women are usually seen as singers or pianists. The reason why women pianists could find their place and were plentiful in the early period jazz groups, is that men were playing brass instruments generally considered to be more 'masculine', hence the need for pianists. Another reason 
for the existence of women pianists is due to middle/upper class families having their daughters take piano lessons as part of their upbringing, as the piano was considered a 'feminine' instrument. Because of these reasons, women have primarily found a place for themselves with the piano in the first periods of jazz. Lil Hardin Armstrong (18981971) and Mary Lou Williams (1910-1981) have an important place in the history of jazz among pioneer women jazz pianists.5 Women who play instruments other than the piano have found opportunities within all-woman bands and family bands created during the 1930s and 40s in the big band period. Due to the conscription during the Second World War, female musicians had found a chance to play in place of male musicians, and orchestras formed entirely of women had become active. International Sweethearts of Rhythm, formed in 1939, is among the most famous of these bands. Trombonist Melba Liston (1926-1999), who was inspired by this band, is an important figure because she broke the prejudice by playing brass with prominent male bands. These women have become pioneers and role models as women instrumentalists within jazz music. Within the following periods, the prominence of women jazz musicians has risen significantly, women jazz instrumentalists as well as vocalists have gained importance in time and have been affective in jazz music. In the 21 st century, there has been progress in comparison to the initial periods of jazz music, even though equality between female and male jazz musicians (especially in orchestras)6 has not been gained, the inadequacy in the amount of role models for women jazz musicians remains an issue, and the stereotypes concerning women jazz musicians continues to a point.

\footnotetext{
5 Marian McPartland (1918-2013) and Hazel Scott (1920-1981) are among famous women pianists in jazz music before 1960. Among the women pianists who gained prominence after the 1960s-70s are Toshiko Akiyoshi (1929), Carla Bley (1936) and Joanne Brackeen (1938). (Please refer to Leslie Gourse, Madame Jazz for other women jazz instrumentalists.)

6 As an example; in 2014, musicians from San Francisco, with the organization of jazz trumpeter and activist Ellen Selling protested gender inequality, the exclusion of women for 26 years from the orchestra, therefore the lack of role models for young women musicians at one of the most important big bands in the world; the Jazz at Lincoln Center Orchestra and have requested 'blind auditions' (candidates to be evaluated behind a curtain during the selection for the orchestra, to avoid discrimination based on gender). Similar protests and campaigns have continued through 2015 and within the 2014-2015 season, the Jazz at Lincoln Center Orchestra has agreed to transparency and blind auditions within the selection process. Yet there still are no female members within the main staff of the orchestra.
} 
After the First World War, jazz music has not only influenced the music of America, but also European art music. Jazz music has jumped across from America to Europe, and has influenced Turkey, therefore the meeting of Turkey with jazz has been through Europe.7

The first jazz singer in Turkey, also known as 'The Mother of Turkish Jazz' was Sevinç Tevs (1926?-1976). After Tevs, jazz singers, Rüçhan Çamay (1931), Ayten Alpman (1929/30?-2012) and Tülay German (1935) have come and can be referred to as the four pioneers of Turkish women jazz vocals.8

\section{Women Jazz Instrumentalists in Turkey}

When going back chronologically in the historical process, the first name that comes up as the woman jazz instrumentalist is Nilüfer Verdi, the first woman jazz pianist in Turkey. She is again followed by pianist Ayşe Tütüncü. Verdi and Tütüncü are also composers. During the period of Verdi and Tütüncü, one also comes across jazz drummer Canan Aykent, who lives in Ankara. Following Nilüfer Verdi, Ayșe Tütüncü and Canan Aykent, is pianist and composer Selen Gülün, who's played jazz in Istanbul for years, recorded albums, worked as an educator and has been living in Japan as of 2017.

On the jazz stage, following singing, the position seen as relatively 'appropriate' for women has been the role of a pianist, hence the large percentage of pianists within all the women jazz instrumentalists in Turkey. The pianist and composer Eda And who lives in Germany, who recorded her first album to feature her own compositions in Turkey in 2018 with musicians who live here, and pianist and composer Bilge Günaydın, who plays an active role in the Turkish jazz scene are among the new generation of jazz pianists in Turkey. New generation of musicians who are especially

\footnotetext{
7 For detailed information regarding the history of jazz in Turkey, please refer to İlhan Mimaroğlu, Caz Sanatı (The Art of Jazz); Cüneyt Sermet, Cazın İçinden (From Within Jazz), The History of European Jazz book (edited by Francesco Martinelli) Turkey chapter (written by Hulya Tuncag) sources that were also used as references within the thesis.

8 A name that cannot go by unmentioned in the field of Turkish jazz vocals is Nükhet Ruacan (19512007), who has also raised many students. Through the trail blazed by Turkish women jazz singers, Randy Esen, Sibel Köse, Elif Çağlar, Ece Göksu and Meltem Ege are among many jazz singers to continue on, as their numbers keep rising.
} 
active in jazz music, but play instruments other than the piano, are double bass player and composer Esra Kayıkçı and bass guitar player and composer Ceyda Köybaşığlu.9

The eight women jazz musicians mentioned above form the subject sources for this study. Though many names came up during the preliminary research before the study, as the research continued, the evaluation of self-determined criteria -mentioned in detail within the thesis (Illbi, 2019)- created boundaries for the list which was used in the generation study below, regarding the eight women jazz musicians based on their dates of birth:

1st Generation (60s): Nilüfer Verdi, Ayşe Tütüncü, Canan Aykent.

2nd Generation (70s): Selen Gülün.

3rd Generation (80s): Esra Kayıkçı, Ceyda Köybaşıoğlu, Eda And, Bilge Günaydın.
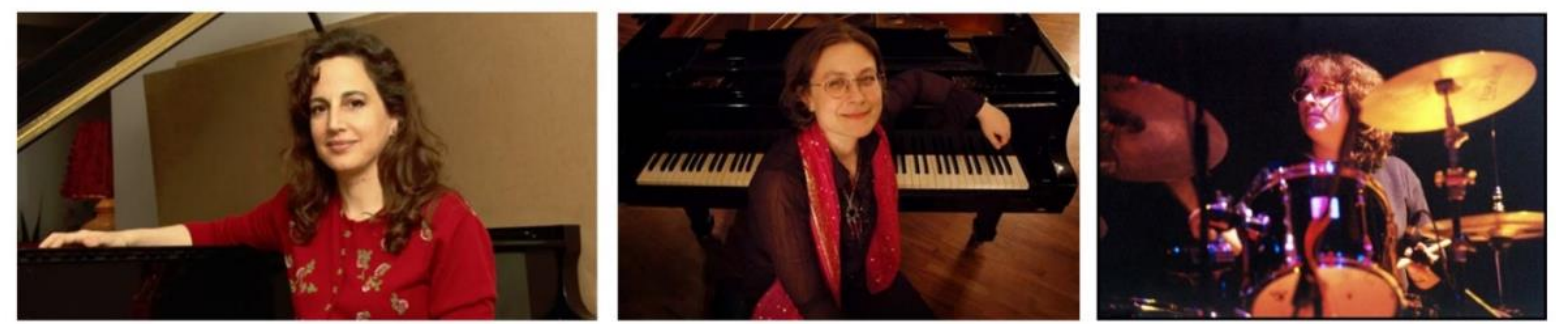

Figure 1: First Generation; Nilüfer Verdi (1956), Ayşe Tütüncü (1960), Canan Aykent (1965).10

9 Polish Drummer Monika Bulanda who has lived in Turkey since 2008, is active in Turkey's music stage, also drummer Nihal Saruhanlı, trombonist Berna Sağdıç who is a member of Istanbul Metropolitan Municipality City Orchestra, trombonist Ebru Kennington again, is a musician of City Orchestra and the Emin Fındıkoğlu+12 orchestra, saxophonist Ezgi Daloğlu who was in the Istanbul Youth Jazz Orchestra that was conducted by pianist and composer Baki Duyarlar, Aslı Özer who is the pianist and composer of Cazzip Project, which is the winner of the 21st Istanbul Jazz Festival Youth Jazz Contest and the first Turkish band that got on stage in the Amersfoort Jazz Festival (in the Netherlands) in May 2019, drummer Buse Şimşek and pianist Maya Muz were not included within the scope of the research, however they have been involved in the jazz scene in Turkey. They weren't included within the scope of the research for reasons such as; some being active in various music genres other than jazz music, some becoming active just recently and some just being active in a single project.

10 http://www.sanattanyansimalar.com/nilufer-verdi-caz-trio-5-mart-ta-erimtan-da/4315,

http://nardisjazz.com/events/ayse-tutuncu-quartet from Canan Aykent's own database. 


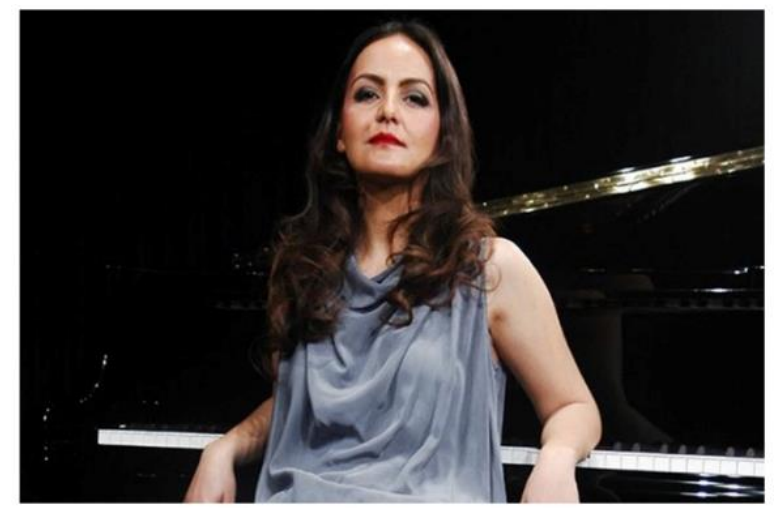

Figure 2: Second Generation; Selen Gülün (1972)11
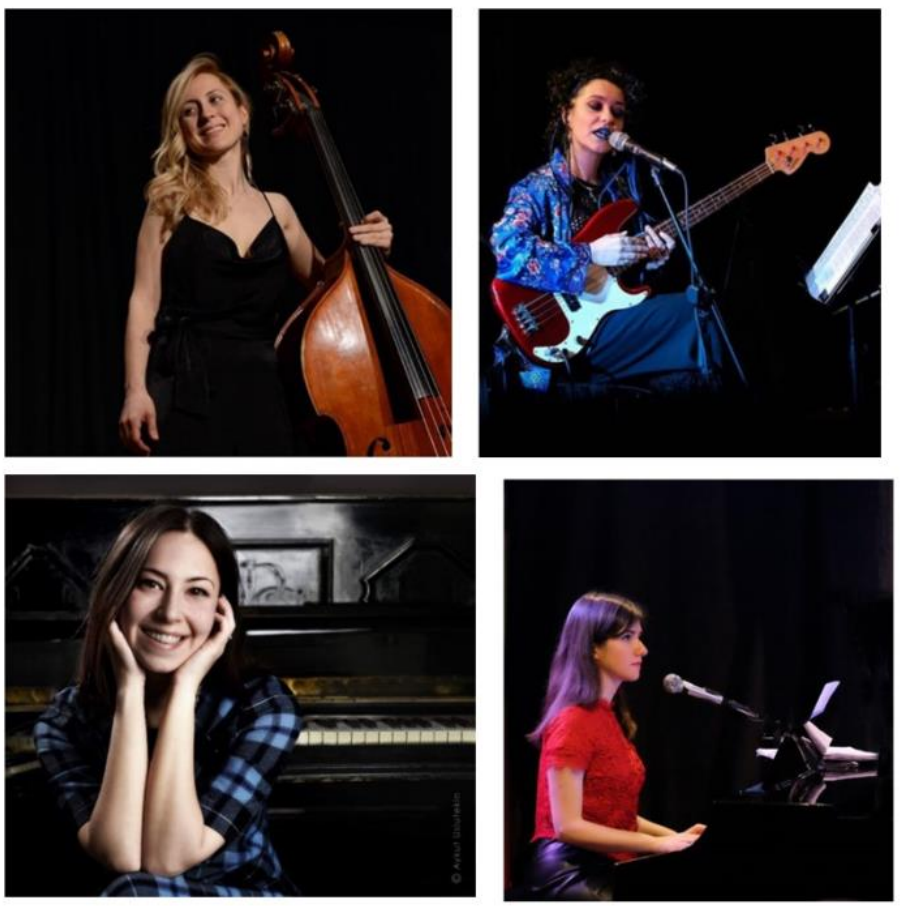

Figure 3: Third Generation; Esra Kayıkçı (1982), Ceyda Köybaşığlu (1983), Eda And (1988), Bilge Günaydın (1989).12

11 https://www.gazeteduvar.com.tr/kultur-sanat/2018/06/23/selen-gulun-kadinlar-matinesi-ilesahnede/

12 Esra Kayıkçı photo credit: Seda Özgüven, Ceyda Köybaşığlu: https://ankaracaz.com/,Eda And photo credit: Aykut Uslutekin, Bilge Günaydın: https://ankaracaz.com/ 
Basic information regarding the subject sources 13 are displayed in Chart 1:

\begin{tabular}{|c|c|c|c|c|c|c|c|c|}
\hline GENERATION & NAME & INSTRUMENT & COMPOSITION & SINGING & $\begin{array}{c}\text { BAND } \\
\text { LEADERSHIP }\end{array}$ & ALBUM(S) & $\begin{array}{c}\text { JAZZ } \\
\text { MUSIC } \\
\text { CAREER } \\
\text { (years) }\end{array}$ & $\begin{array}{l}\text { ACADEMIC } \\
\text { STUDY }\end{array}$ \\
\hline \multirow{3}{*}{$\begin{array}{c}1^{\text {st }} \\
\text { GENERATION }\end{array}$} & N.VERDÍ & Piano & + & & + & 3 & 40 & \\
\hline & A.TÜTÜNCÜ & Piano & + & + & + & 9 & $25+$ & \\
\hline & C.AYKENT & Drum & & & & & $25+$ & $\begin{array}{l}\text { Master's+PhD } \\
\text { thesis }\end{array}$ \\
\hline $\begin{array}{c}2^{\text {nd }} \\
\text { GENERATION }\end{array}$ & S.GÜLÜN & Piano & + & + & + & 7 & 25 & $\begin{array}{l}\text { Master + } \\
\text { Book editing }\end{array}$ \\
\hline \multirow{4}{*}{$\begin{array}{c}3^{\text {rd }} \\
\text { GENERATION }\end{array}$} & E.KAYIKÇI & Double bass & + & + & + & $\begin{array}{l}1 \text { (vocal) + } \\
1 \text { (single) }\end{array}$ & $5+$ & $\begin{array}{l}2 \text { Master's } \\
\text { thesis }\end{array}$ \\
\hline & C.KÖYBAȘIOĞLU & Bass guitar & + & + & + & 1 (single) & 10 & \\
\hline & E.AND & Piano & + & & + & 1 & 5 & Master \\
\hline & B.GÜNAYDIN & Piano & + & & + & 1 & 5 & $\begin{array}{l}\text { Master's } \\
\text { thesis }\end{array}$ \\
\hline
\end{tabular}

Table 1: The Comparison Table of Three Generations14

\section{The Evaluation of Women Jazz Instrumentalists in Turkey within the Gender Context}

"Role is a key concept in sociological theory. It highlights the social expectations attached to particular statuses or social positions..." (Marshall, 1998: 570) Which means that roles are formed by social based expectations. The concept of gender, which also forms the perspective of this research is, in its essence, formed by roles determined by social expectations. What roles are predefined for women by gender, the social expectations required of women who are jazz musicians are and what the socially 'appropriate roles' for women within jazz music are, were researched within this study. Within the detected findings were data such as; singing being the usual role required of women jazz musicians, playing an instrument and/or composing not being associated with women, and that women who were involved in jazz music in capacities other than singing faced bewilderment. An example is Nilüfer Verdi, the first woman jazz pianist of

13 Since any proper biographical information on most of these eight women musicians within this generation study couldn't be found in any obtainable source; the one-on-one interviews conducted for this research, the online resources and background information derived from their own personal archives have been mentioned in the thesis, which constitutes the basis for this study.

${ }_{14}$ Since most of the subject sources have master's degrees/thesis and have had academic activities as well as being musicians, a column has been added to the table regarding their academic studies. 
Turkey, who's stated that it was more probable for a woman in jazz to find a job by being a singer15 (Nilüfer Verdi, personal communication, February 22, 2019).

In jazz, while the role of a singer is seen as 'appropriate' for women, naturally the path is cleared for them, whereas the role of an instrumentalist is a few steps ahead, and women have had to/and still have to struggle for that path. For example, pianist Selen Gülün (2nd Generation) has stated that;

Never ever in Turkey have I ever been invited as a pianist, and until I attended Berklee [College of Music], I was only invited as a singer. Actually, society, willingly or not pushes you towards something like this: "Don't you play just sing, so don't use an instrument use your voice” (Selen Gülün, personal communication, February 12, 2019).

On the other hand, while the role expected of a male jazz musician is the ability to play his instrument 'well' befitting of his status, the role expected of a female jazz musician is that she play her instrument 'very well'. Penina Migdal Glazer and Miriam Slater, in their books Unequal Colleagues: The Entrance of Women into the Professions, 1890-1940 talk about the four strategies women use to combat gender inequality. One of them; the strategy of 'super-performance' fits in accordance with the role of playing 'very well' mentioned previously. For example, Selen Gülün has said; for women jazz musicians to be taken seriously, they have to play "much better" compared to men and also conduct their business "much more orderly, without any mistakes" (Selen Gülün, personal communication, February 12, 2019).

With data gathered throughout this study, specifically within jazz music, the most important reason why women usually lean towards singing, why women jazz instrumentalists are a minority, and why they usually prefer being pianists is the subject of (the) role model.16 For example, when asked about women not leaning towards instruments, Bilge Günaydın (3rd Generation) responded that the low number of women jazz instrumentalists puts potentially influential role models out of reach, and that the

15 It's observed that the role of a singer being a more 'appropriate' role, and one that's more customary for women in jazz is an ongoing social code that provides women a place on the jazz stage and an ease in getting a job due to demand to see the female figure aesthetically or up front -in front- of the musicians on stage.

${ }_{16}$ "A significant other, upon which an individual patterns his or her behavior in a particular social role, including adopting appropriate similar attitudes. Role-models need not be known personally to the individual: some people model their behavior in particular roles on the real and legendary example provided by historical figures." (Marshall, 1998: 572) 
high number of female jazz singers naturally creates a shift towards singing and also that the singer's model is carried to the foreground (Bilge Günaydın, personal communication, April 6, 2019).

Selen Gülün also states that the lack of inclination to play instruments when starting out as a jazz musician is especially due to the knowledge that the road ahead will be a difficult one, because of the low number of role models available. For Gülün, the small number of examples before women who want to be jazz pianists means the struggle to stand out and to be seen among millions from the very start. She adds that; to be assisted by an appropriate emotional state and background requires a courageous and intellectually dense surrounding, and that no such level of cultural consciousness can be said to have matured in Turkey as of yet (Selen Gülün, personal communication, February 12, 2019).

Once again, Selen Gülün has touched on the importance of having role models;

Ayșe Tütüncü can be considered my role model because when I first saw her I was very young. She was on the stage playing the synthesizer as well as singing and playing the piano with the band 'Mozaik'. My God!... That was the first role that gave me courage, when I saw Ayşe and said "So I can do that as well." Therefore, I know how important it is. I myself have tried to stand in that place as well, so I could raise others who came after... (Selen Gülün, personal communication, February 12, 2019)

Pianists Eda And (3rd Generation) and Bilge Günaydın have also talked about the availability of women role models as a need and a source of inspiration when starting out as an instrumentalist in jazz music.

On the topic of women playing instruments in jazz music in Turkey, it has been observed that pianists hold the highest percentage. While the tradition of women pianists being common during the infancy of jazz music in the US could be regarded as one of the causes for this issue, the most important reasons for the prevalence of women jazz pianists over other women jazz instrumentalists could be explained in the following way: Due to the masculinity-femininity characteristics projected onto instruments, the piano is considered a more 'feminine' instrument and is associated with women, therefore girls usually start their music lives with piano lessons and within 
conservatories, among the instruments that girls are lead towards such as the violin, the flute and the piano, because of the common usage of the piano in jazz music, when they want to get into jazz music and better themselves, their piano training makes them lean towards becoming jazz pianists.

According to Sherrie Tucker, "Throughout jazz history singing has been understood as relatively feminine, or an activity in which women could participate without appearing 'abnormal', compared with the playing of brass, reeds, bass, and drums - instruments typically associated with men." (Tucker, 2003: 2) Throughout history, women who've played instruments generally used in jazz music other than the piano have had to face certain prejudices, and have been regarded as 'abnormal' as stated above. Social norms17, while not written, have been accepted by society, so actions that do not fit in with these norms and with the roles of gender are regarded as 'abnormal' by society. Women who play instruments generally associated with men such as drums, bass guitar, double bass and brass instruments, have had to face and struggle with certain stereotypes. As the number of role models keeps increasing, and society grows to understand that these prejudices are just the perspectives formed by the social system, so the stereotypes too, will decrease, and women playing these instruments be normalized. Among the eight subject sources selected for this research, five are pianists, while one is a drummer, one is a bass guitarist, and one is a double bass player. The ratio specific to this research indicates that the selection of instruments other than the piano is fewer in numbers.

Double bass player Esra Kaylkçı (3rd Generation) has stated that she's sometimes had difficulty in carrying her double bass, but that a musician will and can play the instrument that they want to play. While also a singer, Esra Kayıkçı has said that she has been met with surprise and interest when she used her double bass and her voice at the same time on stage (Esra Kayıkçı, personal communication, March 26, 2019). Ceyda Köybaşıoğlu (3rd Generation), who plays bass guitar and sings within her own project, has put forward that the notion of difficulty in doing both at the same time is quite common: "I receive feedback asking me whether I can do both at the same time. Some are

17 "In sociology a norm is a shared expectation of behavior that connotes what is considered culturally desirable and appropriate. Norms are similar to rules or regulations in being prescriptive, although they lack the formal status of rules." (Marshall, 1998: 453) 
positive, but some display pessimism by way of being looked over." (Ceyda Köybaşıŏlu, personal communication, April 22, 2019)

In essence, improvisation, one of jazz music's key aspects can be likened to composing in regards to creative skills being put forth by improvising. As such, with the nature of jazz being so lenient towards improvisation, an important skill that most jazz musicians have, is that of an improviser. About $90 \%$ of the subject sources involved with this research are also composers. The role of composing, again, like playing an instrument, is not one associated with women, due to gender inequality. Throughout history, the low number of women composers, as compared to men, is an important indicator of this fact. Women composers have had to endure and face prejudices throughout history, like they did when playing instruments. An example; "Women have had to develop certain strategies just to prevent unjust negative reviews upon their works because of their sex. One of these is to hide their sex by using their initials on the concert programs." (Özkişi, 2017: 75) An example of data gathered by asking the subject sources about their roles as composers; Eda And has said that when she reached out to musicians to play and work with her on her first album, comprised of her own compositions, her works were well liked, and some male musicians were surprised that she was able to compose them as a woman (Eda And, personal communication, April 5, 2019).

Within the societal system, women not getting the opportunity to express themselves also constitutes a disadvantage in jazz music. Jazz music, generally, is the music of selfexpression; therefore, in a geography where women still can't express themselves in many fields, it may seem usual for women who express themselves within jazz music with their instruments and/or their own works to be a minority. One of the key elements of jazz music is that it's based upon improvising by stepping away from central rules. In a patriarchal society, individuals, unknowingly, take on certain roles and these roles become visible through certain actions. Turkey too, is an androcentric geography, and while this situation has started to unravel through a slow movement of consciousness and awareness, some codes from the past make themselves apparent under certain circumstances. Within the patriarchal system, women are expected to be quiet, self-sacrificing and obeying, to remain in the house, and to refrain from stepping forward as much as possible. All these expectations and gender roles may willingly or otherwise reflect upon women's feelings and actions, so becoming free and improvising 
may take a period of adjustment. This process can only be improved with equality of opportunity. For women to improve themselves in jazz, they have to be constantly playing, and for that, both jazz bands and jazz stages have to embrace equality of opportunity.

In jazz, being a composer brings with it being a band leader. This is because in the tradition of jazz, composers play their compositions in their groups with their instruments, and the groups that play their compositions usually carry their names and are led by them. The status of being a leader is limited to women, not only in the field of music, but in many others. Society is not used to seeing women in leadership positions. For example, pianist Ayşe Tütüncü (1st Generation) has said that women musicians as leaders are usually as unexpected as women having a say in society and governance (Ayşe Tütüncü, personal communication, March 22, 2019).

When Eda And was studying jazz composition in Germany, she was conducting her own composition in school, and said that she was not taken seriously and constantly criticized by the group she was leading, while her male classmate wasn't met with such behavior, therefore the mistreatment she received was because of her sex (Eda And, personal communication, April 5, 2019).

Like in many other occupations, women come across the disadvantage of being a minority in jazz music as well. For example; Ayşe Tütüncü has expressed the feeling of loneliness this situation brings as such;

There is a nice, fraternal, equal atmosphere when the group we're playing in is comprised of two women and two men... But when men outnumber women, there tends to be a situation where a male sense of humor and male style of conversation is generally felt heavily. Actually, being seen out there in numbers really does change a lot. Things change where women are abler to be together, or the women to men ratio is closer in numbers. $A$ male musician would feel alone too if he were a minority amongst many women. Being a minority creates the feeling of loneliness... (Ayșe Tütüncü, personal communication, March 22, 2019)

As stated in the documentary Miss Representation, American female activist Marian Wright Edelman's phrase "You can't be what you can't see”, young women can't imagine 
being somewhere where there are no women, or if women are a minority. It's what's seen that inspires the idea of what's possible. For this reason, like stated in the subject of role models, the visibility of women jazz musicians carries a significant importance, as they will be the examples for future generations to come. In this study, the recognition of women jazz instrumentalists was questioned, questions like whether the subject sources had to work extra in order to be seen in the sector of jazz music and to find a place for themselves, and what sort of processes they had to go through within this context were asked.

For example, drummer Canan Aykent (1st Generation) has stated that in her view, in order to be seen as a musician, the individual has to work hard regardless of their sex and that in order to be successful in jazz, it takes a lot of effort, and that it has less to do with gender, and more to do with skills and effort (Canan Aykent, personal communication, April 23, 2019).

On the other hand, Selen Gülün has stated that in order to be seen and accepted in jazz, women have to write their own music, that this issue had an effect on her leaning towards composing and becoming a group leader:

Women have to write their music... You get to a point where you have to be a leader yourself, because no one invites you as a musician, but you want to play and so you start creating your own music so you can create an offering. So that you can gather people around you. This in fact, is a point of struggle, creating your own music and your own domain. I was in the need to do just that. I wanted to do it regardless, but I would've had to do it even if I didn't want to. (Selen Gülün, personal communication, April 9, 2019)

It has been observed through this research that male jazz musicians usually play with males, that they generally don't work with female instrumentalists as group members and that women create a workplace for themselves by forming all-woman bands. After all these observations, it could be said that while male jazz musicians take place as group members in groups formed and led by women who write their own music, in their own groups they generally work with male musicians. As mentioned in Leslie Gourse's book Madame Jazz, "It isn't necessarily chauvinism alone that still keeps most men playing with men. Habit usually guides them... So men usually play with musicians they have always worked with: other men...For the women players, the breaks have to come 
from leaders who... keep their minds and options open. Or the women must get their own gigs as leaders..." (Gourse, 1995: 12)

The subject sources were consulted to find whether the male-dominated world of jazz has an influence on the creativity and enthusiasm of women musicians. For example, pianist Selen Gülün has shared her experiences as such:

Of course it affects. As a woman, throughout your life you're subjected to a lot of behaviors that make you question your existence in this profession, within education etc. There were many times when I was depressed, and as an example, this is what led me to leave Turkey for Berklee. (Selen Gülün, personal communication, April 9, 2019)

Generally, subject sources have stated that their creativity was not affected by the male dominated jazz stage, but that their enthusiasm and motivations were. The experiences and comments shared by subject sources are indications of gender inequality. It is only possible that there are examples whose spirit was broken, enthusiasm diminished and, in the end, lost their struggle when their motivation ran out. As such, it's important to increase awareness about gender inequality, to construct this consciousness, and to be involved in activities that encourage the rise of women instrumentalists in jazz music.

\section{Conclusion}

Within this article, women jazz instrumentalists have been examined within the gender context, and the structure of the study has been shaped by interviews conducted with the subject sources.

The topic that comes up when questions like 'why have there been no great/important women artists/writers/scientists' in various fields are directed towards women returns the result that they're not 'absent', but a 'minority', and the reason for that, is historically, gender inequality; one of just many social injustices that affects women's educational and career opportunities negatively.

On the topic of 'why have there been no... women', for example, English writer Virginia Woolf, in one of feminism's most prominent works; A Room of One's Own, talks about “If Shakespeare had a sister..." (and if she too wanted to be a poet...) that this sister's fictionalized 'potential career' wouldn't go anywhere, and that she would end up taking her own life. Keeping in mind the fact that women are not as frequently mentioned in 
music as men until the 20th century, in the times of Shakespeare (16th century), this assumption could only end up as predicted.18

When looking at the 20 th century, with the effect of the feminist movement, there has been significant progress in areas of women gaining their basic rights, in finding a place in education, and in joining the work force. In the 21 st century, this state has been improving, but the equality between men and women throughout every facet of society has still not been established, and women's ongoing struggle concerning their existence and recognition has not been completed. Throughout human history, although coexisting with men, women, who, for some reason, have been left out by male dominated literature, perhaps have begun to gain more recognition in each and every field, as the concept of gender has in time, started to come under critical view.

Within this research, while the perception that 'there are no' women jazz instrumentalists has been done away with, and it's been determined that they're a minority when compared to men, it turns out that they're still not a 'minor'ity as they're generally thought of, and that the reasons as to 'why' they're a minority are connected to parameters based in gender.

When going through the literature of women's works in Turkey, the bibliography based on gender is generally limited to the field of arts, and are limited in numbers in the field of jazz music. Using publications such as Gölgenin Kadınları (The Women of Shadow), Sanatın Gölgedeki Kadınları (The Women of Art within the Shadows), with an emphasis on being left in the shadows of art history written by men, parallel to male dominance within jazz history as well, the purpose of examining women who've been left in the shadows or left out, should not be to put them where 'they should be' or to fill gaps, but to take a close look at women's productivity, their creativity, and the strategies developed by them to overcome difficulties, to make yesterday's experiences visible/recognizable within today's practices.

18 Another point that destroys the 'why have there been no... women' argument are women who've had to conceal their true identities as women, and have gone in history as men to be able to exist as writers, musicians etc. For example, the most famous French woman writer Aurore Dupin (1804-1876), who's been involved with 19th century Polish composer F. Chopin for a while, uses the pseudonym George Sand, and inspires progressive women like Mary Ann Evans (1819-1880) who writes in England with the pseudonym George Eliot, and Elizabeth Barrett Browning (1806-1861) who gets her poems published as translations because of women poets not being perceived well in her times. On the other hand, jazz musician 'Billy' Tipton (1914-1989) whose real name is Dorothy, but can only subsist by disguising herself as a man, is an example from jazz history. 
As stated by some of the subject sources, within the seminars they've attended abroad or the education they've received, the number of examples of women musicians have been limited when compared to men. While a worldwide issue, the status of women in jazz music being a minority is higher in ratio in Turkey. Selen Gülün, who lives in Japan, and Eda And, who lives in Germany, have conveyed that the instances of women jazz instrumentalists abroad are much higher when compared to Turkey. In these countries, the idea of possibly becoming a woman jazz musician is spreading among women, musicians and within society thanks to the visibility of these examples. As the number of women jazz instrumentalists rises in Turkey, as more visible examples become available, so will the perspective of society change, and further boost the rising number of women jazz musicians. It could be possible to start locally, to point out where these questions/problems rise and to help increase this ratio with studies like this.

As determined from the statements put forward by many of the women instrumentalists who've taken part in this research, the need that every individual feels is to see an example/role model in the path they will choose for themselves; therefore, the need for women to see role models in jazz music is one of the most interesting determinations of this study. The higher the number of role models, the brighter and less handicapped the road will be for women jazz musicians who will follow in their path. Just like a relay race, the number of women in arts and sciences continues to rise, thanks to the torch lit by the women movement's that started only 200 years ago. Therefore, from Marie Curie, the first woman scientist to win a Nobel Prize, to the first Turkish woman stage actress Afife Jale, from the first Turkish primadonna Leyla Gencer, to the first Turkish jazz vocalist Sevinç Tevs, from the first woman jazz pianist in Turkey Nilüfer Verdi to the youngest member of the generation study of this research; pianist Bilge Günaydın, the existence of 'sheroes' (a play on the word hero that refers to women/women heroes who are appreciated because of their courage, extraordinary accomplishments, noble qualities) of this relay race holds great importance for jazz musicians both of today and tomorrow.

As Virginia Woolf writes in her book, there have been many famous male thinkers throughout history who've clearly put forward their hatred of women, their ideas about women being incapable of dealing with 'serious' matters, that they never could create/be creative, that they could never compose etc. However, studies conducted on 
the matter provide information that when any work of art is examined without information regarding the artist who created it, there can be no definitive conclusion about the gender of the artist. Taking this into consideration, focusing on the 'reason's as to why women are a minority in jazz, like in so many other fields, urgent steps have to be taken to remove the causes. Nature's 'law of balance' is one of opposites in harmony. For example, like the black and white in the yin-yang symbol being featured in the same circle, and like the thesis-antithesis forming the synthesis, the roles of women and men have to be balanced on the level of collective consciousness. When the balance is broken, it affects both sides of the dualism. Although usually, it's the negatively affected side that tries to recreate balance at first, this by itself becomes inadequate. As such, the effort put forward to ensure the balance between men and women can only go so far, when the effort is only by women.

Thus, for male jazz musicians to develop an awareness of the gender inequality within jazz, to be aware of the female jazz musicians left on the broken side of the balance who start their careers off in the same sector in a disadvantaged state; and to make an effort to balance the situation even though they're on the advantageous side will form a solid step forward in creating this balance. Moving from there, for male jazz musicians to create 'equality of opportunity' by giving place to women colleagues within 'male' groups, and for festival and club managers to provide women with equality of opportunity with the same mindset may be the accelerators for the change that's been in the making for so long, and for it to be permanent.

As can be observed in the generation study conducted within this research, the number of women jazz instrumentalists keeps rising, and this is promising with regards to establishing equality amongst men and women in jazz music. Over the course of this research, up and coming women jazz musicians have been identified, and within future research they may be subjects of, the generation study started here can be used. And so, as new names expected to get additional recognition are added to women jazz instrumentalists, the generations that follow may be in the majority when compared to those who came before. As this research, and others like this find a place in academic literature, the male-dominated literature will be left behind, and a more equal playing field can be formed. This study, which aims to form a qualitative memory within the 
academic research on women, is at the same time a gesture of respect towards all the women who've put the effort within this field.19

\section{REFERENCES}

Butler, Judith. (1990). Gender Trouble: Feminism and The Subversion of Identity. New York: Rutledge, Chapman \& Hall, Inc.

Gourse, Leslie. (1995). Madame Jazz: Contemporary Women Instrumentalists. New York: Oxford University Press.

Grant, Margaret Jean. (2006). “A Feminist Analysis of Francis Poulenc's Sonata for Oboe and Piano" Ph.D. Dissertation, The Graduate School of the University of Cincinnati, Cincinnati: USA.

İlbi, Deniz and Karaol, Esra. (2018). "Puccini ve Wagner Operalarında Kadın Karakterlerin İşlenişi" [Female Characters in Puccini and Wagner Operas]. [4th International Music and Dance Congress] Gülbeyaz, Kürşad and Yazıcl, Tarkan (Eds.), (pp. 130-138). Bodrum, Muğla: Müzik Eğitimi Publications. Retrieved from https://www.academia.edu/38095415/Puccini_ve_Wagner_Operalar\%C4\%B1nda_Kad \%C4\%B1n_Karakterlerin_\%C4\%B0\%C5\%9Fleni\%C5\%9Fi_Female_Characters_in_Pucci ni_and_Wagner_Operas_.

İlbi, Deniz. (2019). “Türkiye'de Enstrüman Çalan Kadın Caz Müzisyenlerinin Toplumsal Cinsiyet Bağlamında İncelenmesi" (Women Jazz Instrumentalists in Turkey within the Context of Gender) Master's Thesis, Istanbul University Social Sciences Institute, Istanbul: Turkey.

Marshall, Gordon. (1998). A Dictionary of Sociology. Oxford: Oxford University Press.

Mimaroğlu, İlhan K. (2016). Caz Sanatı (The Art of Jazz). Istanbul: Pan Publishing.

Newsom, Jennifer Siebel. [Director] (2011). Miss Representation [Documentary]. USA: Netflix.

19 The many possible solutions to balance recognition of women (jazz musicians) within society can be found in the thesis study that formed the basis of this article. 
Nochlin, Linda. (2014). "Why Have There Been No Great Women Artists?” Retrieved from https://www.artnews.com/art-news/retrospective/why-have-there-been-nogreat-women-artists-4201/

Özkişi, Zeynep Gülçin. (2009). “Toplumsal Cinsiyet Bağlamında Türkiye'de Kadın Besteciler: Tanzimat'tan Günümüze Osmanlı İmparatorluğu ve Türkiye Cumhuriyeti'nde Kadın Besteciler ve Yapıtları" (Female Composers in Turkey in the Context of Gender: In Ottoman Empire and Turkish Republic, from Tanzimat Era to Today, Female Composers and Their Works) Ph.D. Dissertation, Ylldız Teknik University Social Sciences Institute, Istanbul: Turkey.

Özkişi, Zeynep Gülçin. (2017). "Müzikte Cinsiyet Rollerine İlişkin Yargılar: Kanon, Gettolaşma ve Toplumsal Cinsiyet Bağlamında Kadın Besteci Sorunu” (Judgements Regarding Gender Roles in Music: Canon, Ghettoization and the Issue of the Woman Composer in the Gender Context) Kadın ve Müzik (Women and Music), Ed. Ersoy Çak, Şeyma and Beşiroğlu, Ş. Şehvar: pp. 63-97. Istanbul: Milenyum Publications.

Tucker, Sherrie. (2003). "Women in Jazz" Grove Music Online. https://doi.org/10.1093/gmo/9781561592630.article.J730100

Turner, Bryan S. (Ed.) (2006). The Cambridge Dictionary of Sociology. Cambridge: Cambridge University Press.

Uyar, Yaprak Melike. (2013). “Türkiye'de Caz Müziğinde Kadın: Çalgı İcracılığına Toplumsal Cinsiyet Merkezli Yaklaşımlar" (Gender Issues and Performance Practices in Jazz: Women Instrumentalists in the Jazz Scene of Turkey) Porte Akademik-Toplumsal Cinsiyet (Gender), (6): 86-97.

Woolf, Virginia. (1977). A Room of One's Own. London: Grafton 